\title{
Molnupiravir, an Oral Antiviral Treatment for COVID-19
}

William Fischer, MD, Institute for Global Health and Infectious Disease, Division of Pulmonary Diseases and Critical Care Medicine, The University of North Carolina and Chapel Hill, Chapel Hill, NC, USA.

Joseph J. Eron Jr, MD, Department of Medicine, Division of Infectious Diseases, The University of North Carolina and Chapel Hill, Chapel Hill, NC, USA.

Wayne Holman, MD, Ridgeback Biotherapeutics LP, Miami, FL, USA.

Myron S. Cohen, MD, Institute for Global Health and Infectious Disease, The University of North Carolina and Chapel Hill, Chapel Hill, NC, USA.

Lei Fang, MS, Pharstat Inc., Raleigh, NC, USA

Laura J. Szewczyk, BS, Ridgeback Biotherapeutics LP, Miami, FL, USA.

Timothy P Sheahan, PhD, Department of Epidemiology, The University of North Carolina and Chapel Hill, Chapel Hill, NC, USA.

Ralph Baric, Department of Epidemiology, The University of North Carolina and Chapel Hill, Chapel Hill, NC, USA.

Katie R. Mollan, MS, Gillings School of Global Public Health, School of Medicine, The University of North Carolina and Chapel Hill, Chapel Hill, NC, USA.

Cameron R. Wolfe, MBBS MPH, Department of Medicine, Division of Infectious Diseases, Duke University Medical Center, Durham, NC, USA. 
Elizabeth R. Duke, MD MA, Fred Hutchinson Cancer Research Center, University of Washington, Seattle, WA, USA.

Masoud M. Azizad, MD, Valley Clinical Trials, Inc., Northridge, CA, USA.

Katyna Borroto-Esoda, MS, KBE Consulting, Raleigh, NC, USA.

David A. Wohl, MD, Institute for Global Health and Infectious Disease, Division of Pulmonary Diseases and Critical Care Medicine, The University of North Carolina and Chapel Hill, Chapel Hill, NC, USA.

Amy James Loftis, BSc, Institute for Global Health and Infectious Disease, The University of North Carolina and Chapel Hill, Chapel Hill, NC, USA.

Paul Alabanza, BSc, Lineberger Comprehensive Cancer Center, The University of North Carolina and Chapel Hill, Chapel Hill, NC, USA.

Felicia Lipansky, Ridgeback Biotherapeutics LP, Miami, FL, USA.

Wendy P. Painter, MD MPH, Ridgeback Biotherapeutics LP, Miami, FL, USA.

Corresponding author: Wendy P. Painter, MD, MPH, Ridgeback Biotherapeutics, Miami, FL, USA.

\begin{abstract}
Background: Easily distributed oral antivirals are urgently needed to treat coronavirus disease-2019 (COVID-19), prevent progression to severe illness, and block transmission of severe acute respiratory syndrome coronavirus 2 (SARS-CoV-2). We report the results of a
\end{abstract}


medRxiv preprint doi: https://doi.org/10.1101/2021.06.17.21258639; this version posted June 17, 2021. The copyright holder for this preprint (which was not certified by peer review) is the author/funder, who has granted medRxiv a license to display the preprint in perpetuity.

All rights reserved. No reuse allowed without permission.

Phase 2a trial evaluating the safety, tolerability, and antiviral efficacy of molnupiravir in the treatment of COVID-19 (ClinicalTrials.gov NCT04405570).

Methods: Eligible participants included outpatients with confirmed SARS-CoV-2 infection and symptom onset within 7 days. Participants were randomized 1:1 to $200 \mathrm{mg}$ molnupiravir or placebo, or 3:1 to molnupiravir (400 or $800 \mathrm{mg}$ ) or placebo, twice-daily for 5 days. Antiviral activity was assessed as time to undetectable levels of viral RNA by reverse transcriptase polymerase chain reaction and time to elimination of infectious virus isolation from nasopharyngeal swabs.

Results: Among 202 treated participants, virus isolation was significantly lower in participants receiving $800 \mathrm{mg}$ molnupiravir $(1.9 \%)$ versus placebo $(16.7 \%)$ at Day $3(\mathrm{p}=0.02)$. At Day 5 , virus was not isolated from any participants receiving 400 or $800 \mathrm{mg}$ molnupiravir, versus $11.1 \%$ of those receiving placebo $(\mathrm{p}=0.03)$. Time to viral RNA clearance was decreased and a greater proportion overall achieved clearance in participants administered $800 \mathrm{mg}$ molnupiravir versus placebo $(\mathrm{p}=0.01)$. Molnupiravir was generally well tolerated, with similar numbers of adverse events across all groups.

Conclusions: Molnupiravir is the first oral, direct-acting antiviral shown to be highly effective at reducing nasopharyngeal SARS-CoV-2 infectious virus and viral RNA and has a favorable safety and tolerability profile. 
medRxiv preprint doi: https://doi.org/10.1101/2021.06.17.21258639; this version posted June 17, 2021. The copyright holder for this preprint (which was not certified by peer review) is the author/funder, who has granted medRxiv a license to display the preprint in perpetuity.

All rights reserved. No reuse allowed without permission.

\section{Introduction}

Severe acute respiratory syndrome (SARS) coronavirus 2 (SARS-CoV-2), the virus responsible for coronavirus disease-2019 (COVID-19), has caused more than 166,000,000 confirmed infections and 3,400,000 deaths worldwide as of 23 May $2021 .^{1}$

Studies have shown associations between high SARS-CoV-2 nasopharyngeal ribonucleic acid (RNA) levels and both hospitalization rates and infectious (replication competent) virus isolation. ${ }^{2-7}$ Additionally, animal studies found similar associations between viral RNA levels and transmission. ${ }^{8}$ However, no therapies have been shown to eliminate infectious virus and prevent transmission. Thus, there is an urgent need for oral antiviral therapies that can be easily distributed on a scale that meets global demand, reduce disease progression, and prevent SARS-CoV-2 transmission.

Molnupiravir, the prodrug of the ribonucleoside analog $\beta-\mathrm{D}-\mathrm{N}^{4}$-hydroxycytidine (NHC), is rapidly converted in plasma to NHC and then to the active $5^{\prime}$-triphosphate form by host kinases. ${ }^{9}$ The active 5'-triphosphate serves as a competitive substrate for virally-encoded RNA-dependent RNA polymerase (RdRp), and once incorporated into nascent viral RNA, induces an antiviral effect via accumulation of mutations that increase with each viral replication cycle. ${ }^{9-11}$ Preclinical studies reveal broad-spectrum antiviral activity against coronaviruses, including SARS-CoV-2 with a high barrier to resistance. ${ }^{12,13}$ In humanized mouse models, molnupiravir treatment and prophylaxis reduced SARS-CoV, SARS-CoV-2, high-risk SARS-like bat coronaviruses, and Middle East respiratory syndrome coronavirus (MERS-CoV) virus replication and pathogenesis. ${ }^{14,15}$ In a SARS-CoV-2 ferret model, molnupiravir treatment completely 
blocked transmission to untreated animals, emphasizing that early treatment could potentially prevent secondary spread of SARS-CoV-2. ${ }^{8}$

Molnupiravir has been shown to be safe and well tolerated in a first-in-human, Phase 1, trial in healthy volunteers. ${ }^{9}$ We report the results of a Phase $2 \mathrm{a}$, double-blind, placebo-controlled, randomized, multicenter trial designed to evaluate the safety, tolerability, and antiviral activity of molnupiravir dosed twice-daily for 5 days in the treatment of patients with mild to moderate COVID-19. Hypotheses included that molnupiravir would decrease the time to clearance of SARS-CoV-2 virus in nasopharyngeal swabs and be safe and well tolerated in symptomatic SARS-CoV-2-infected adults.

\section{Methods}

\section{Trial Design and Conduct}

Adults aged $\geq 18$ years were eligible if they tested positive for SARS-CoV-2 infection within 96 hours and had symptoms of COVID-19 within 7 days of treatment initiation (Day 1). Antiviral activity, safety, and tolerability were assessed for 28 days following study treatment initiation. Nasopharyngeal swabs were collected on Days 1 (baseline), 3, 5, 7, 14, and 28 for measurement of antiviral activity by reverse transcriptase polymerase chain reaction (RT-PCR) and infectious virus isolation. Safety laboratories were assessed on Days 1, 3, 5, 7, 14, and 28 and adverse events were monitored throughout.

The protocol was approved by WCG institutional review board and written informed consent was obtained from each participant prior to study entry. The study design and analyses are detailed in supplementary information. 
medRxiv preprint doi: https://doi.org/10.1101/2021.06.17.21258639; this version posted June 17, 2021. The copyright holder for this preprint (which was not certified by peer review) is the author/funder, who has granted medRxiv a license to display the preprint in perpetuity.

All rights reserved. No reuse allowed without permission.

\section{Randomization and Intervention}

Participants were randomized 1:1 to $200 \mathrm{mg}$ molnupiravir or matching placebo or 3:1 to molnupiravir (400 or $800 \mathrm{mg}$ ) or placebo. Doses were administered orally twice-daily for 5 days and dose escalations occurred following review of safety and virology data from this and other studies of molnupiravir.

\section{Antiviral Efficacy}

The primary antiviral efficacy outcome was time to viral RNA clearance, as measured by quantitative RT-PCR of nasopharyngeal swabs using a laboratory-developed test based on the Centers for Disease Control and Prevention 2019-nCoV emergency use authorization assay. Time to viral RNA clearance was defined as the first timepoint where viral RNA was achieved and was below the limit of quantitation $(<1,018$ copies/mL). Secondary antiviral efficacy outcomes were time to infectious virus elimination from nasopharyngeal swabs and median viral RNA change from baseline on Days 3, 5, and 7. Infectious virus isolation was performed using Vero C1008 cells and assessed by quantitative RT-PCR of viral RNA in culture medium at 2 and 5 days post inoculation. ${ }^{3,16}$ Samples were considered positive if the supernatant had at least 1,000 copies/mL SARS-CoV-2 RNA at 2 days post inoculation or if the relative fold-change in RNA copy number from cultures days 2 to 5 days post inoculation was $>5$. Next generation sequencing of RdRp was performed on samples collected on Day 5 to analyze nucleotide changes and confirm the mechanism of action. 
medRxiv preprint doi: https://doi.org/10.1101/2021.06.17.21258639; this version posted June 17, 2021. The copyright holder for this preprint (which was not certified by peer review) is the author/funder, who has granted medRxiv a license to display the preprint in perpetuity.

All rights reserved. No reuse allowed without permission.

\section{Safety and Tolerability}

The primary safety and tolerability objectives assessed adverse events that were Grade 3 or higher and those that led to early treatment discontinuation.

\section{Clinical and Immunologic Outcomes}

Severities and durations of self-reported COVID-19 symptoms (a secondary objective) were collected daily using a symptom diary. Plasma samples were collected to evaluate immune response and serology using antigen-capture enzyme-linked immunosorbent assays. ${ }^{17-19}$

\section{Statistical Analyses}

Time to response for viral RNA negativity was summarized using Kaplan-Meier methodology. Median time to response and cumulative probability of response by visit (with $95 \%$ confidence interval) was analyzed by treatment group. Comparisons of treatment effects were performed using log-rank tests. The number and percentage of subjects who were negative for infectious virus isolation were summarized and between-group comparisons were conducted using Fisher's exact test. Dose-response assessments were performed using the exact Cochran-Armitage trend test.

Treatment comparisons between active drug and placebo groups for SARS-CoV-2 nasopharyngeal viral load change from baseline were analyzed using a mixed model for repeated measures, with restricted maximum likelihood estimation and an unstructured covariance matrix. The model included fixed effects of treatment, study visit, days since COVID-19 symptom onset,

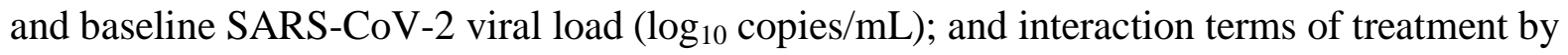
visit, days since COVID-19 symptom onset by visit, and baseline SARS-CoV-2 viral load by 
medRxiv preprint doi: https://doi.org/10.1101/2021.06.17.21258639; this version posted June 17, 2021. The copyright holder for this preprint (which was not certified by peer review) is the author/funder, who has granted medRxiv a license to display the preprint in perpetuity.

All rights reserved. No reuse allowed without permission.

visit. The estimated mean treatment difference for active minus placebo at each visit is presented with the $95 \%$ confidence interval and corresponding p-value. Comparisons of next-generation sequencing data between treatments were performed using a two-sample t-test, based on the average number of treatment-emergent nucleotide changes. Analyses were conducted using SAS Version 9.4 (SAS Institute Inc., Cary NC) and two-sided tests were performed using an alpha of 0.05 for treatment comparisons. Adjustments for multiple testing were not performed.

\section{Results}

\section{Participant Demographics and Clinical Characteristics}

Two hundred and four participants were randomized and 202 received at least 1 dose of molnupiravir or placebo between 19 June 2020 and 25 January 2021 at 10 sites in the USA

(Figure 1; Table 1). Seven participants discontinued participation due to adverse events, lost to follow-up, physician-decision/participant withdrawal. Baseline SARS-CoV-2 antibody prevalence was greater in the $800 \mathrm{mg}$ molnupiravir group (35.3\%) compared to the placebo group (18.2\%; Table 1).

\section{Isolation of Infectious SARS-CoV-2 Virus}

Infectious virus was isolated from $43.5 \%$ (74/170) of evaluable nasopharyngeal swabs at baseline (Table 2 and Figure 2a). On Day 3, infectious virus isolation decreased significantly to $1.9 \%(1 / 53)$ of participants administered $800 \mathrm{mg}$ molnupiravir compared to $16.7 \%(9 / 54)$ of participants administered placebo $(\mathrm{p}=0.02)$. Infectious virus isolation also decreased on Day 5 in participants administered 400 or $800 \mathrm{mg}$ molnupiravir, with zero having infectious virus isolated in these groups (0/42 and 0/53 respectively) compared to $11.1 \%(6 / 54)$ of placebo 
medRxiv preprint doi: https://doi.org/10.1101/2021.06.17.21258639; this version posted June 17, 2021. The copyright holder for this preprint (which was not certified by peer review) is the author/funder, who has granted medRxiv a license to display the preprint in perpetuity.

All rights reserved. No reuse allowed without permission.

recipients $(\mathrm{p}=0.03)$. The difference in infectious virus isolation remained significant for 400 and $800 \mathrm{mg}$ molnupiravir groups (compared to placebo) on Day 5 when analysis was limited to those who were antibody negative at baseline and/or those with infectious virus isolation present at baseline (Supplementary Table 3 and Supplementary Table 4). The difference in infectious virus isolation remained significant for $800 \mathrm{mg}$ molnupiravir when compared to concurrent placebo recipients (Supplementary Table 5). Overall, there was a clear dose response in infectious virus isolation, with the proportion of participants with infectious virus isolated significantly lower in the 400 or $800 \mathrm{mg}$ molnupiravir compared to $200 \mathrm{mg}$ molnupiravir or placebo on Days 3 and 5 $(p$-values $=0.010$ and 0.003 , respectively; Table 2$)$ and the dose response was significant on Day 5 when analysis was limited to participants who had infectious virus isolation at baseline (pvalue $=0.004 ;$ Supplementary Table 3)

\section{Time to SARS-CoV-2 Clearance of Viral RNA}

Time to clearance of viral RNA in nasopharyngeal swabs was the primary endpoint of this study and was significantly reduced in participants receiving $800 \mathrm{mg}$ molnupiravir (median: 14 days) compared to those administered placebo (log-rank p-value $=0.013$; Table 2 and Figure $2 b$ ). The reduction in time to clearance of viral RNA between $800 \mathrm{mg}$ molnupiravir and placebo was greater and remained significant (medians: 14 and 27 days, respectively; $p$-value $=0.001$ ) when analysis was limited to participants who were negative for antibodies at baseline (Supplementary Table 7). The proportion of participants who achieved SARS-CoV-2 negativity by end of study was also greater for those administered $800 \mathrm{mg}$ molnupiravir (92.5\%) compared with $91.3 \%$, $78.7 \%$, and $80.3 \%$ for 200 and $400 \mathrm{mg}$ molnupiravir and placebo, respectively. 
medRxiv preprint doi: https://doi.org/10.1101/2021.06.17.21258639; this version posted June 17, 2021. The copyright holder for this preprint (which was not certified by peer review) is the author/funder, who has granted medRxiv a license to display the preprint in perpetuity.

\section{Change from Baseline in SARS-CoV-2 Viral Load}

The decrease in viral RNA from baseline to Days 3 to 28 was greater for the $800 \mathrm{mg}$ molnupiravir group than any other group (Table 2 and Figure 2c). For participants administered 400 or $800 \mathrm{mg}$ molnupiravir, the least squares mean viral load change from baseline was significantly greater on Day 5 when compared to placebo, with differences in least squares means of -0.434 and $-0.547 \log _{10}$ copies $/ \mathrm{mL}(\mathrm{p}=0.03$ and 0.006$)$, respectively. Additionally, for participants administered $800 \mathrm{mg}$ molnupiravir, the least squares mean viral load change from baseline was also significantly greater on Day 7 compared to placebo, with a least squares mean difference of $-0.534 \log _{10}$ copies $/ \mathrm{mL}(\mathrm{p}=0.006)$. The reduction in viral load from baseline to Day 5 between 800 mg molnupiravir and placebo remained significant during sensitivity analyses of participants who were negative for antibodies at baseline (least squares mean difference of $-0.613 \log _{10}$ copies/mL; $\mathrm{p}=0.002$; Supplementary Table 6) and when compared to concurrent placebo (least squares mean difference of $-0.376 \log _{10}$ copies $/ \mathrm{mL} ; \mathrm{p}=0.045$; Supplementary Table 8).

\section{SARS-CoV-2 Antibody Detection}

Participants were tested for SARS-CoV-2- specific immunoglobulin (Ig) A, IgM, and IgG at baseline and on Days 7 and 28. The proportions of participants with any antibody to SARS-CoV-2 at baseline varied between the groups, with $15.0 \%, 30.0 \%, 35.3 \%$, and $18.2 \%$ in the 200, 400, $800 \mathrm{mg}$ molnupiravir and placebo groups respectively. By Day 28, $99.2 \%$ of molnupiravir-treated participants had developed antibodies to SARS-CoV-2, compared to $96.5 \%$ of those administered placebo. 
medRxiv preprint doi: https://doi.org/10.1101/2021.06.17.21258639; this version posted June 17, 2021. The copyright holder for this preprint (which was not certified by peer review) is the author/funder, who has granted medRxiv a license to display the preprint in perpetuity.

All rights reserved. No reuse allowed without permission.

Next Generation Sequencing of SARS-CoV-2 RNA-Dependent RNA Polymerase

Genotypic changes in the RdRp occurred at a higher rate among participants who received molnupiravir compared to placebo. On average, 5.7 nucleotide changes in the RdRp were observed following treatment with placebo. By comparison, the average number of nucleotide changes in RdRp following molnupiravir treatment was two-fold greater (10.9) and was statistically significant $(\mathrm{p}=0.02)$ supporting viral error catastrophe as the mechanism of action. ${ }^{11}$

\section{Safety and Tolerability}

Molnupiravir and placebo were associated with few, and mainly low-grade, adverse events (Table 3). The incidence of treatment-associated adverse events was lowest in the molnupiravir $800 \mathrm{mg}$ group. The only adverse events reported by more than 4 participants were headache, insomnia, and increased alanine aminotransferase. Two (1.4\%) adverse events led to discontinuation of molnupiravir compared with 1 (1.6\%) for placebo. Grade 3 or higher adverse events occurred in $5.0 \%$ and $8.1 \%$ in the molnupiravir and placebo groups, respectively. There were no treatment- or dose-related trends in hematology or clinical chemistry data during the study.

Four serious adverse events occurred and resulted in hospitalization, comprising one (1.6\%) participant administered placebo who had hypoxia, two (3.2\%) participants administered $400 \mathrm{mg}$ molnupiravir (cerebrovascular accident and decreased oxygen saturation), and one (1.8\%) participant administered $800 \mathrm{mg}$ molnupiravir who had acute respiratory failure (Table 3). Treatment was discontinued in all 4 participants. Following completion, 1 death due to COVID-19 occurred in a participant administered placebo outside of the 28-day time window. 
medRxiv preprint doi: https://doi.org/10.1101/2021.06.17.21258639; this version posted June 17, 2021. The copyright holder for this preprint (which was not certified by peer review) is the author/funder, who has granted medRxiv a license to display the preprint in perpetuity.

All rights reserved. No reuse allowed without permission.

\section{Clinical Endpoints}

A greater proportion of participants administered molnupiravir reported their health as poor or fair $(68.2 \%)$ at baseline than those administered placebo $(50.0 \%)$. There were no notable differences in symptom duration or severity between the treatment groups over the 28 days.

\section{Discussion}

In this Phase 2a, randomized, double-blind, placebo-controlled, clinical trial, molnupiravir was well tolerated and associated with potent antiviral efficacy as evidenced by significantly reduced infectious virus isolation, time to elimination of SARS-CoV-2 RNA, increased proportion of participants that cleared SARS-CoV-2 RNA, and a greater reduction in SARS-CoV-2 viral RNA from baseline compared to placebo in outpatients with COVID-19. Four days after treatment initiation, there was no infectious virus isolated from any participants who received 400 or 800 mg molnupiravir.

The reduction in the time to clearance of viral RNA, the greater proportion of participants with SARS-CoV-2 viral RNA negativity, and the greater change in viral RNA levels from baseline in participants treated with $800 \mathrm{mg}$ molnupiravir compared to placebo support the findings of a significant decrease in infectious virus isolation. These results remained significant even when accounting for time from symptom onset, viral RNA level, and seropositivity. Importantly, only $22.8 \%$ of participants had evidence of a humoral immune response at baseline, indicating that randomization occurred early in the clinical course of infection. However, by Day 28, 92.1\% were antibody positive, demonstrating that early treatment with molnupiravir had an antiviral effect without inhibiting the development of a humoral immune response. 
medRxiv preprint doi: https://doi.org/10.1101/2021.06.17.21258639; this version posted June 17, 2021. The copyright holder for this preprint (which was not certified by peer review) is the author/funder, who has granted medRxiv a license to display the preprint in perpetuity.

All rights reserved. No reuse allowed without permission.

In clinical trials of COVID-19 therapeutics, antiviral efficacy against SARS-CoV-2 has been assessed by measuring viral RNA levels; however, detection of viral RNA does not confirm the replication competence of the virus. We believe demonstration of the ability of treatment to reduce and eliminate infectious SARS-CoV-2 is an essential consideration; in observational studies, SARS-CoV-2 virus isolation decreases with time, and persistence of infectious virus is associated with disease severity and host immune status. ${ }^{4,20,21}$ In otherwise healthy adults with mild to moderate disease, infectious virus has been isolated up to 10 days after symptom onset. $^{3,7,20,21}$ In this, the largest outpatient study to evaluate infectious virus isolation to date, infectious SARS-CoV-2 was isolated from $11.1 \%$ of placebo recipients at study Day 5, a mean 9 to 10 days from symptom onset, and treatment with molnupiravir was found to accelerate the clearance of infectious virus. Critically, this is the first clinical trial to demonstrate the ability of treatment to reduce and eliminate infectious SARS-CoV-2 in patients with COVID-19.

Safety analyses from this trial were consistent with those from a Phase 1 trial of molnupiravir and support ongoing clinical development. ${ }^{9}$ Overall, molnupiravir was well tolerated with no increase in treatment-related or serious adverse events compared to participants administered placebo. There were no safety signals or evidence of hematologic, renal, or hepatic toxicity at any dose.

Importantly, this clinical trial was designed to evaluate the antiviral efficacy of molnupiravir and was not powered to evaluate clinical endpoints, such as symptom duration or hospitalization. However, a Phase 2/3 study is ongoing to evaluate the effect of molnupiravir on symptom duration and severity, emergency department visits, and hospitalizations (ClinicalTrials.gov Identifier: NCT04575597). Another limitation included imbalances in the randomization, with a greater proportion of seropositive individuals and a trend toward a lower viral load at baseline 
medRxiv preprint doi: https://doi.org/10.1101/2021.06.17.21258639; this version posted June 17, 2021. The copyright holder for this preprint (which was not certified by peer review) is the author/funder, who has granted medRxiv a license to display the preprint in perpetuity.

All rights reserved. No reuse allowed without permission.

among those randomized to $800 \mathrm{mg}$ molnupiravir compared to placebo. However, differences in infectious virus isolation at Day 5, time to clearance of viral RNA, and reductions in viral load from baseline to Day 5 remained significant when analysis was limited to participants who were antibody negative at baseline. Among participants who were negative for antibodies at baseline, there was no difference in baseline viral load between the $800 \mathrm{mg}$ molnupiravir and placebo groups. An additional limitation is the use of pooled placebo in the analyses; however, differences in virus isolation and viral load reduction on Day 5 remained significant when analysis was limited to comparisons between $800 \mathrm{mg}$ molnupiravir and concurrent placebo (Supplementary Table 7). These sensitivity analyses indicate that the antiviral efficacy demonstrated in this study is not due to imbalances in either seropositivity, trends in viral RNA level at baseline, or the use of a pooled placebo group.

Currently, two combination intravenous monoclonal antibody cocktails have been granted emergency use authorization in an attempt to reduce nasopharyngeal SARS-CoV-2 RNA, medical visits, and hospitalizations; however, the logistical challenges of intravenous therapies limit timely administration to patients who may benefit most from these important treatments. $^{2,22-24}$ This trial provides strong biological evidence that supports development of molnupiravir as an oral agent to reduce infectious virus replication and interrupt progression of COVID-19 in early stages of disease. Current evidence suggests that uninterrupted viral replication is a major sign of progression to more severe disease. ${ }^{2,5}$ Critically, molnupiravir can be produced at scale and does not require cold transportation or infection control infrastructure for administration.

In conclusion, the results of this trial demonstrate the safety, tolerability, and antiviral efficacy of molnupiravir to reduce replication of SARS-CoV-2 and accelerate clearance of infectious virus 
medRxiv preprint doi: https://doi.org/10.1101/2021.06.17.21258639; this version posted June 17, 2021. The copyright holder for this preprint (which was not certified by peer review) is the author/funder, who has granted medRxiv a license to display the preprint in perpetuity.

All rights reserved. No reuse allowed without permission.

and support ongoing trials of molnupiravir to prevent progression of COVID-19 and eliminate onward transmission of SARS-CoV-2. ${ }^{8}$

\section{Acknowledgements}

The authors with to acknowledge the participants and the following sites for their dedication and contributions to the study: Valley Clinical Trials (Northridge, CA), University of North Carolina (Chapel Hill, NC), Fred Hutchinson (Seattle, WA), Care United Research (Forney, TX), Benchmark Research (Colton, CA), FOMAT Medical Research (Oxnard, CA), Indago Research \& Health Center (Hiahleah, FL), Wake Forest University (Winston-Salem, NC), Duke University (Durham, NC), and NOLA Research Works (New Orleans, LA). Additionally, the authors with to acknowledge Dr Mark Stead of Covance for supporting the preparation of this manuscript and the randomization support provided by the National Center for Advancing Translational Sciences (NCATS; UL1TR002489) and the UNC Center for AIDS Research (P30 AI050410). Molnupiravir was invented at Drug Innovations at Emory (DRIVE) LLC, a not-for-profit biotechnology company wholly owned by Emory University, and with partial funding support from the US government. Since licensed by Ridgeback Biotherapeutics, all funds used for the development of molnupiravir by Ridgeback Biotherapeutics have been provided by Wayne and Wendy Holman and Merck.

\section{References}

1. World Health Organisation. Weekly epidemiological update on COVID-19 - 25 May 2021

[Internet]. Coronavirus Dis. COVID-19 Pandemic. [cited 2021 May 26];Available from: https://www.who.int/publications/m/item/weekly-epidemiological-update-on-covid-19---25may-2021 
medRxiv preprint doi: https://doi.org/10.1101/2021.06.17.21258639; this version posted June 17, 2021. The copyright holder for this preprint (which was not certified by peer review) is the author/funder, who has granted medRxiv a license to display the preprint in perpetuity.

All rights reserved. No reuse allowed without permission.

2. Chen P, Nirula A, Heller B, et al. SARS-CoV-2 Neutralizing Antibody LY-CoV555 in Outpatients with Covid-19. N Engl J Med 2021;384(3):229-37.

3. Wölfel R, Corman VM, Guggemos W, et al. Author Correction: Virological assessment of hospitalized patients with COVID-2019. Nature 2020;588(7839):E35-E35.

4. van Kampen JJA, van de Vijver DAMC, Fraaij PLA, et al. Duration and key determinants of infectious virus shedding in hospitalized patients with coronavirus disease-2019 (COVID19). Nat Commun 2021;12(1):267.

5. Liu Y, Yan L-M, Wan L, et al. Viral dynamics in mild and severe cases of COVID-19. Lancet Infect Dis 2020;20(6):656-7.

6. Chen J, Qi T, Liu L, et al. Clinical progression of patients with COVID-19 in Shanghai, China. J Infect 2020;80(5):e1-6.

7. Bullard J, Dust K, Funk D, et al. Predicting Infectious Severe Acute Respiratory Syndrome Coronavirus 2 From Diagnostic Samples. Clin Infect Dis Off Publ Infect Dis Soc Am 2020;71(10):2663-6.

8. Cox RM, Wolf JD, Plemper RK. Therapeutically administered ribonucleoside analogue MK4482/EIDD-2801 blocks SARS-CoV-2 transmission in ferrets. Nat Microbiol 2021;6(1):118.

9. Painter WP, Holman W, Bush JA, et al. Human Safety, Tolerability, and Pharmacokinetics of Molnupiravir, a Novel Broad-Spectrum Oral Antiviral Agent with Activity Against SARS-CoV-2. Antimicrob Agents Chemother 2021;65(5):e02428-20. 
medRxiv preprint doi: https://doi.org/10.1101/2021.06.17.21258639; this version posted June 17, 2021. The copyright holder for this preprint

(which was not certified by peer review) is the author/funder, who has granted medRxiv a license to display the preprint in perpetuity.

All rights reserved. No reuse allowed without permission.

10. Painter GR, Bowen RA, Bluemling GR, et al. The prophylactic and therapeutic activity of a broadly active ribonucleoside analog in a murine model of intranasal venezuelan equine encephalitis virus infection. Antiviral Res 2019;171:104597.

11. Agostini ML, Pruijssers AJ, Chappell JD, et al. Small-molecule antiviral $\beta-D-N 4-$ hydroxycytidine inhibits a proofreading-intact coronavirus with a high genetic barrier to resistance. J Virol 2019;93(24):e01348-19.

12. Sheahan TP, Sims AC, Zhou S, et al. An orally bioavailable broad-spectrum antiviral inhibits SARS-CoV-2 and multiple endemic, epidemic and bat coronavirus. Sci Transl Med 2020;12(541):eabb5883.

13. Pruijssers AJ, George AS, Schäfer A, et al. Remdesivir Inhibits SARS-CoV-2 in Human Lung Cells and Chimeric SARS-CoV Expressing the SARS-CoV-2 RNA Polymerase in Mice. Cell Rep 2020;32(3):107940.

14. Wahl A, Gralinski LE, Johnson CE, et al. SARS-CoV-2 infection is effectively treated and prevented by EIDD-2801. Nature 2021;591(7850):451-7.

15. Menachery VD, Yount BL, Debbink K, et al. A SARS-like cluster of circulating bat coronaviruses shows potential for human emergence. Nat Med 2015;21(12):1508-13.

16. Aydillo T, Gonzalez-Reiche AS, Aslam S, et al. Shedding of Viable SARS-CoV-2 after Immunosuppressive Therapy for Cancer. N Engl J Med 2020;383(26):2586-8. 
medRxiv preprint doi: https://doi.org/10.1101/2021.06.17.21258639; this version posted June 17, 2021. The copyright holder for this preprint (which was not certified by peer review) is the author/funder, who has granted medRxiv a license to display the preprint in perpetuity. All rights reserved. No reuse allowed without permission.

17. Markmann AJ, Giallourou N, Bhowmik DR, et al. Sex disparities and neutralizing antibody durability to SARS-CoV-2 infection in convalescent individuals. MedRxiv Prepr Serv Health Sci 2021;10.1101/2021.02.01.21250493.

18. Premkumar L, Segovia-Chumbez B, Jadi R, et al. The receptor binding domain of the viral spike protein is an immunodominant and highly specific target of antibodies in SARS-CoV-2 patients. Sci Immunol 2020;5(48).

19. González F, Vielot NA, Sciaudone M, et al. Seroepidemiology of SARS-CoV-2 infections in an urban Nicaraguan population. MedRxiv Prepr Serv Health Sci $2021 ; 10.1101 / 2021.02 .25 .21252447$.

20. Folgueira MD, Luczkowiak J, Lasala F, Pérez-Rivilla A, Delgado R. Prolonged SARS-CoV2 cell culture replication in respiratory samples from patients with severe COVID-19. Clin Microbiol Infect Off Publ Eur Soc Clin Microbiol Infect Dis 2021;27(6):886-91.

21. Singanayagam A, Patel M, Charlett A, et al. Duration of infectiousness and correlation with RT-PCR cycle threshold values in cases of COVID-19, England, January to May 2020. Euro Surveill Bull Eur Sur Mal Transm Eur Commun Dis Bull 2020;25(32):2001483.

22. Gottlieb RL, Nirula A, Chen P, et al. Effect of Bamlanivimab as Monotherapy or in Combination With Etesevimab on Viral Load in Patients With Mild to Moderate COVID-19: A Randomized Clinical Trial. JAMA 2021;325(7):632-44.

23. Weinreich DM, Sivapalasingam S, Norton T, et al. REGN-COV2, a Neutralizing Antibody Cocktail, in Outpatients with Covid-19. N Engl J Med 2021;384(3):238-51. 
medRxiv preprint doi: https://doi.org/10.1101/2021.06.17.21258639; this version posted June 17, 2021. The copyright holder for this preprint

(which was not certified by peer review) is the author/funder, who has granted medRxiv a license to display the preprint in perpetuity.

All rights reserved. No reuse allowed without permission.

24. Regeneron Pharmaceuticals, Inc. Phase 3 Prevention Trial Showed $81 \%$ Reduced Risk of Symptomatic SARS-CoV-2 Infections with Subcutaneous Administration of REGEN$\mathrm{COV}^{\mathrm{TM}}$ (casirivimab with imdevimab) [Internet]. Cision PR Newswire. 2021 [cited 2021

May 12];Available from: https://www.prnewswire.com/news-releases/phase-3-preventiontrial-showed-81-reduced-risk-of-symptomatic-sars-cov-2-infections-with-subcutaneousadministration-of-regen-cov-casirivimab-with-imdevimab-301266366.html 
Table 1. Demographics and Baseline Characteristics

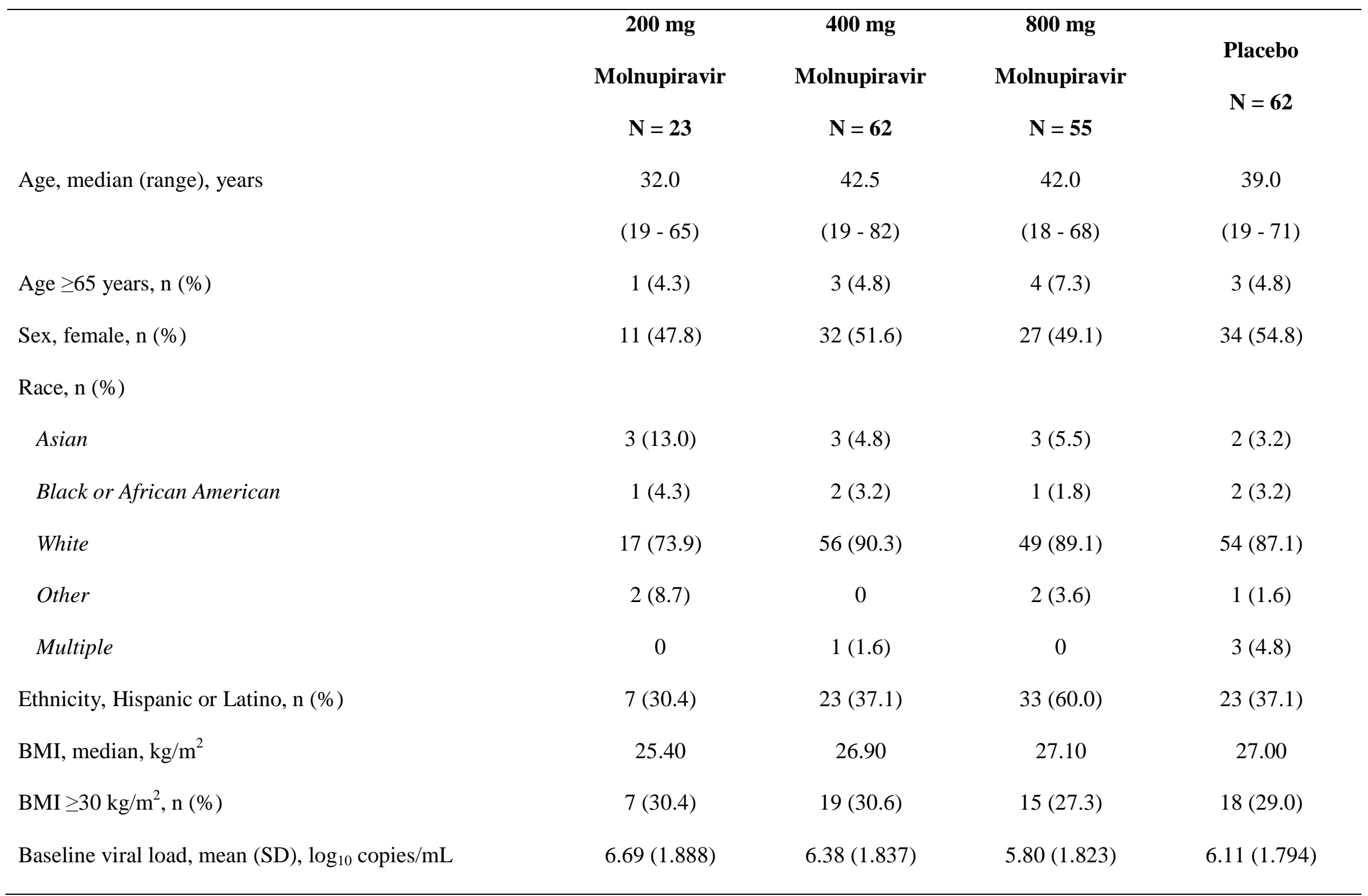




\begin{tabular}{|c|c|c|c|c|}
\hline Baseline viral load, median (range), $\log _{10}$ copies $/ \mathrm{mL}$ & 7.25 & 6.72 & 6.12 & 6.40 \\
\hline & $(3.0-9.5)$ & $(3.0-9.9)$ & $(3.0-9.4)$ & $(3.0-9.3)$ \\
\hline \multirow[t]{2}{*}{ Days from symptom onset, median (range), $\mathrm{n}$} & 4.00 & 4.85 & 4.60 & 4.55 \\
\hline & $(1.8-7.0)$ & $(2.5-7.1)$ & $(1.4-7.1)$ & $(1.8-7.5)$ \\
\hline At least 1 risk factor for severe disease, $\mathrm{n}(\%)$ & $15(65.2)$ & $37(59.7)$ & $33(60.0)$ & $37(59.7)$ \\
\hline SARS-CoV-2 antibody positive on Day $1, \mathrm{n} / \mathrm{N}^{*}(\%)$ & $3 / 20(15.0)$ & $15 / 50(30.0)$ & $18 / 51(35.3)$ & $10 / 55(18.2)$ \\
\hline
\end{tabular}

Abbreviation: $\mathrm{BMI}=$ body mass index; Ig = immunoglobulin; $\mathrm{n}=$ numbers of participants; $\mathrm{SD}$ = standard deviation.

$* \mathrm{~N}=$ number of participants with an antibody status. 
Table 2. Summary of SARS-CoV-2 Infectivity and Virology

\begin{tabular}{|c|c|c|c|c|}
\hline \multicolumn{5}{|c|}{ Percentage of Participants Positive for Infectious SARS-CoV-2 Virus } \\
\hline & $\begin{array}{c}200 \mathrm{mg} \\
\text { Molnupiravir }\end{array}$ & $\begin{array}{c}400 \mathrm{mg} \\
\text { Molnupiravir }\end{array}$ & $\begin{array}{c}\mathbf{8 0 0} \mathrm{mg} \\
\text { Molnupiravir }\end{array}$ & Placebo \\
\hline Day $1, \mathrm{n} / \mathrm{N}(\%)$ & $11 / 22(50.0)$ & $18 / 43(41.9)$ & $20 / 52(38.5)$ & $25 / 53(47.2)$ \\
\hline Day $3, \mathrm{n} / \mathrm{N}(\%)$ & $4 / 22(18.2)$ & $5 / 43(11.6)$ & $1 / 53(1.9)$ & $9 / 54(16.7)$ \\
\hline Fisher's exact p-value & $>0.99$ & 0.57 & 0.016 & \\
\hline Dose response p-value & & & & 0.010 \\
\hline Day $5, \mathrm{n} / \mathrm{N}(\%)$ & $1 / 22(4.5)$ & $0 / 42(0.0)$ & $0 / 53(0.0)$ & $6 / 54(11.1)$ \\
\hline Fisher's exact p-value & 0.67 & 0.03 & 0.03 & \\
\hline Dose response p-value & & & & 0.003 \\
\hline
\end{tabular}

\section{Time to SARS-CoV-2 Viral RNA Negativity}

\begin{tabular}{|c|c|c|c|c|}
\hline & $\begin{array}{c}200 \mathrm{mg} \\
\text { Molnupiravir }\end{array}$ & $\begin{array}{c}400 \mathrm{mg} \\
\text { Molnupiravir }\end{array}$ & $\begin{array}{c}800 \text { mg } \\
\text { Molnupiravir }\end{array}$ & Placebo \\
\hline Participants with Response, $\mathrm{n} / \mathrm{N}(\%)$ & $21 / 23(91.3)$ & 48/61 (78.7) & $49 / 53(92.5)$ & 49/61 (80.3) \\
\hline Median time to response $(95 \% \mathrm{CI})$, days & $22.0(15.0,28.0)$ & $27.0(15.0,28.0)$ & $14.0(13.0,14.0)$ & $15.0(15.0,27.0)$ \\
\hline Log-rank p-value & 0.56 & 0.73 & 0.013 & \\
\hline
\end{tabular}




\begin{tabular}{|c|c|c|c|c|}
\hline \multicolumn{5}{|c|}{ Change from Baseline in SARS-CoV-2 Viral Load $\left(\log _{10} \operatorname{copies} / \mathrm{mL}\right)$} \\
\hline & $\begin{array}{c}200 \mathrm{mg} \\
\text { Molnupiravir }\end{array}$ & $\begin{array}{c}400 \mathrm{mg} \\
\text { Molnupiravir }\end{array}$ & $\begin{array}{c}800 \mathrm{mg} \\
\text { Molnupiravir }\end{array}$ & Placebo \\
\hline Day $3, \mathrm{n} / \mathrm{N}$ & $23 / 23$ & $58 / 61$ & $51 / 53$ & $56 / 61$ \\
\hline Least squares mean (SE) & $-0.783(0.189)$ & $-0.941(0.118)$ & $-1.050(0.115)$ & $-0.847(0.127)$ \\
\hline Difference in least squares mean & 0.064 & -0.094 & -0.203 & \\
\hline $95 \% C I$ & $-0.397,0.525$ & $-0.438,0.250$ & $-0.543,0.137$ & \\
\hline$p$-value & 0.78 & 0.59 & 0.24 & \\
\hline Day $5, \mathrm{n} / \mathrm{N}$ & $23 / 23$ & $56 / 61$ & $52 / 53$ & $57 / 61$ \\
\hline Least squares mean (SE) & $-1.471(0.212)$ & $-1.754(0.128)$ & $-1.867(0.126)$ & $-1.320(0.150)$ \\
\hline Difference in least squares mean & -0.150 & -0.434 & -0.547 & \\
\hline $95 \% C I$ & $-0.674,0.374$ & $-0.825,-0.043$ & $-0.935,-0.159$ & \\
\hline$p$-value & 0.57 & 0.030 & 0.006 & \\
\hline Day $7, \mathrm{n} / \mathrm{N}$ & $23 / 23$ & $51 / 61$ & $49 / 53$ & $56 / 61$ \\
\hline Least squares mean (SE) & $-2.028(0.202)$ & $-2.263(0.119)$ & $-2.485(0.107)$ & $-1.952(0.157)$ \\
\hline Difference in least squares mean & -0.076 & -0.311 & -0.534 & \\
\hline $95 \% C I$ & $-0.591,0.438$ & $-0.702,0.079$ & $-0.910,-0.157$ & \\
\hline
\end{tabular}




$\begin{array}{lccc}\begin{array}{l}\text { p-value } \\ \text { Day 14, n/N }\end{array} & 0.77 & 0.12 & 0.006 \\ \text { Least squares mean (SE) } & 23 / 23 & 53 / 61 & 48 / 53 \\ \text { Difference in least squares mean } & -2.884(0.091) & -2.840(0.065) & -3.040(0.040) \\ \text { 95\% CI } & -0.019 & 0.026 & -0.175 \\ p \text {-value } & -0.298,0.260 & -0.220,0.272 & -0.400,0.050 \\ \end{array}$

Abbreviations: $\mathrm{CI}=$ confidence interval; $\mathrm{n}=$ number of observations; $\mathrm{N}=$ number of participants; $\mathrm{SE}=$ standard error. 


\section{Number (\%) of participants experiencing Molnupiravir $200 \mathrm{mg}$ Molnupiravir $400 \mathrm{mg}$ Molnupiravir $800 \mathrm{mg} \quad$ Placebo}

\begin{tabular}{|c|c|c|c|c|}
\hline an event & $\mathrm{N}=23$ & $\mathrm{~N}=62$ & $\mathrm{~N}=55$ & $\mathrm{~N}=62$ \\
\hline Any adverse event & $11(47.8)$ & $20(32.3)$ & $11(20.0)$ & $18(29.0)$ \\
\hline \multicolumn{5}{|c|}{ Adverse events reported by $>5 \%$ subjects in any group } \\
\hline Dizziness & $2(8.7)$ & $1(1.6)$ & 0 & 0 \\
\hline Insomnia & $2(8.7)$ & $1(1.6)$ & $1(1.8)$ & $4(6.5)$ \\
\hline Any adverse event grade 3 or higher & $1(4.3)$ & $2(3.2)$ & $4(7.3)$ & $5(8.1)$ \\
\hline $\begin{array}{l}\text { Any adverse event leading to disconti } \\
\text { from study drug }\end{array}$ & 0 & $1(1.6)$ & $1(1.8)$ & $1(1.6)$ \\
\hline Any serious adverse event & 0 & $2(3.2)$ & $1(1.8)$ & $1(1.6)$ \\
\hline Any adverse event leading to death & 0 & 0 & 0 & $1(1.6)^{*}$ \\
\hline
\end{tabular}

\section{Abbreviation: $\mathrm{n}=$ number of participants.}

* The subject had an adverse event of hypoxia that led to death. This occurred 31 days after discontinuation from the study following completion of study assessments and was not recorded in the study database but was recorded in the safety database. 


\section{Figure Legends}

\section{Figure 1. Study Flow Chart}

Abbreviations: AE = adverse event; COVID-19 = coronavirus disease-2019; mITT = modified intent to treat; $\mathrm{n}=$ number of participants; $\mathrm{PP}=$ per protocol; $\mathrm{SARS}-\mathrm{CoV}-2=$ severe acute respiratory virus coronavirus 2 .

The mITT population included all subjects who were randomized into the study and had at least 1 post baseline viral RNA assessment. The PP population included subjects in the safety population who had no important protocol deviations leading to exclusion from the PP population and had completed the Day 28 follow-up visit. The safety population included all subjects who were randomized and took at least 1 dose of study drug. Subjects were analyzed according to the treatment they actually received.

\section{Figure 2. SARS-CoV-2 Infectivity and Virology}

(A) Proportion of participants positive (red) for SARS-CoV-2 infectious virus; participants who are negative for SARS-CoV-2 infectious virus are in blue. (B) Kaplan-Meier plot of time to clearance of SARS-CoV-2 RNA by treatment (200 mg molnupiravir [red], $400 \mathrm{mg}$ molnupiravir [blue], $800 \mathrm{mg}$ molnupiravir [green], and placebo [black]). (C) Least squares mean change from baseline in SARS-CoV-2 RNA ( $\log _{10}$ copies/mL) for the modified intent to treat population (200 mg molnupiravir [red], $400 \mathrm{mg}$ molnupiravir [blue], $800 \mathrm{mg}$ molnupiravir [green], and placebo [black]).

Abbreviations: RNA = ribonucleic acid; SARS-CoV-2 = severe acute respiratory syndrome 2 coronavirus 2. 


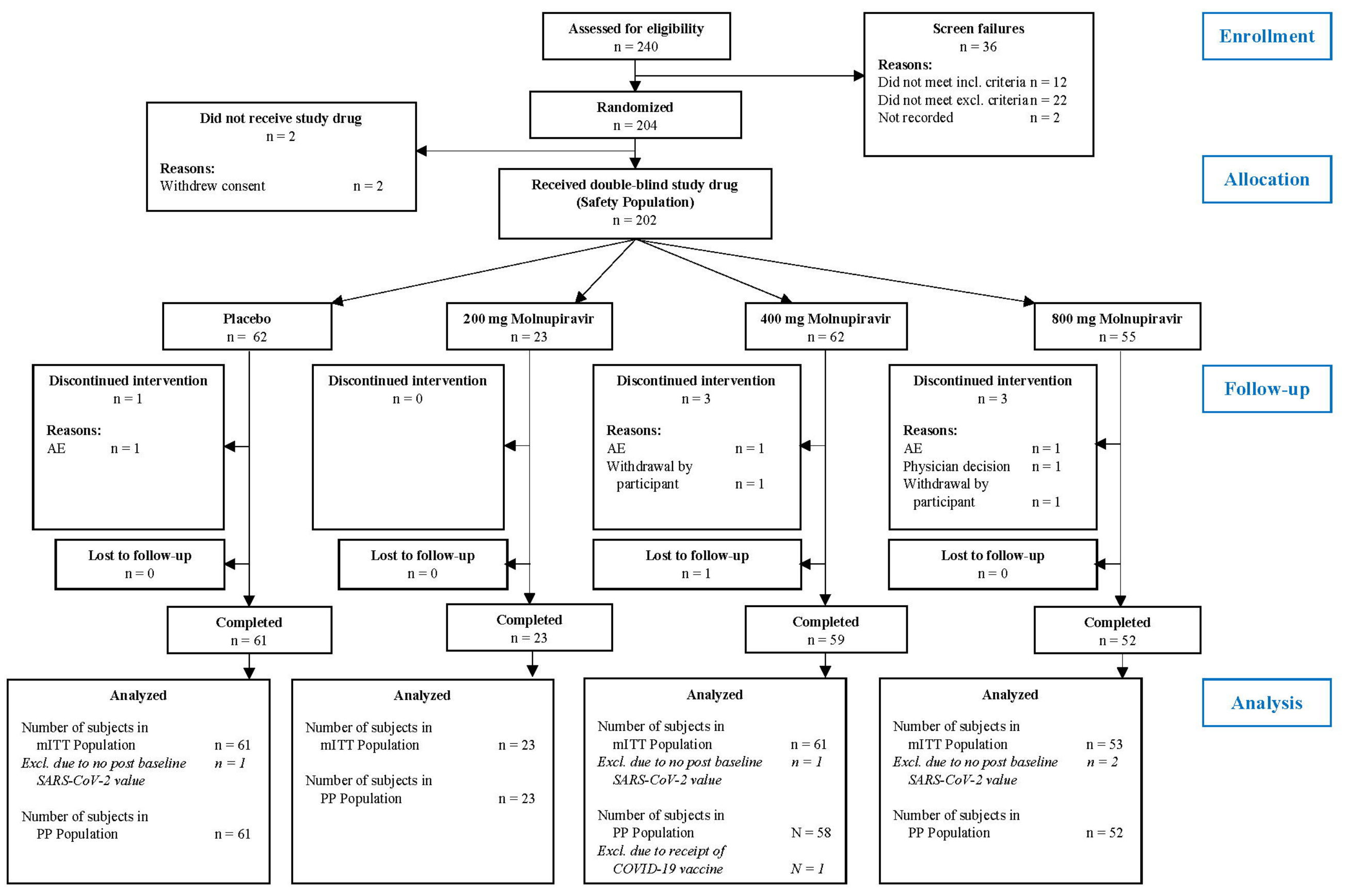


